\title{
A CROSS-SECTIONAL SURVEY TO ASSESS THE STATUS OF BMI AND ATTITUDE OF SELF CARE AMONG MEDICAL STUDENTS OF PRIVATE AYURVEDA MEDICAL COLLEGE KERALA
}

\section{Dr Aswathy V* \\ Dr Umadevi K N Dr Vivek Unni K K}

Assistant professor Department of Kriyasareeram Vishnu Ayurveda College Shoranur. *Corresponding Author Dr Nivil K P Associate professor Department of Kriyasareeram Vishnu Ayurveda College Shoranur. Associate professor Department of Rachanasareeram Vishnu Ayurveda College Shoranur.

Assistant professor Department of Rachanasareeram Vishnu Ayurveda College Shoranur.

\section{KEYWORDS : self-care, medical students, BMI}

\section{INTRODUCTION}

Health care profession is considered as most stressful and difficult profession that demands compromises. Health professionals are prone to lifestyle disorders and early aging owing to their work load, untimely food, inadequate sleep and sedentary work. Unfortunately, self-care among health care professionals and students are very less. It's important to develop self-care attitude among the medical students along with medical education they receive. Self-care maintenance should develop as one's habit and to develop such habit, health status assessment and self-care measures should be periodically encouraged in every medical colleges. Present study took place as a part of National Service Scheme campaign to assess the health status of our medical students and a short assessment of their attitude towards selfcare.

\section{METHODOLOGY}

\section{Objective of the study}

To assess the status of BMI among students of a private Ayurveda medical college

To assess the attitude of students in maintenance of self-care

To assess prevalence of particular health problems in student community

- Study design: Cross sectional study

- Study setting: Vishnu Ayurveda college Kulappulli Kerala

Ethical clearance: Permission was obtained from the Principal of the institution

Informed consent was taken from each participant.

\section{Data collection technique}

A proforma was generated after validation of the measurement tool by 4 experts. Proforma had 3 parts

1. BMI evaluation

2. Knowledge- attitude-activity questionnaire: With 6 questions

- Knowledge - 1 open ended question

- Attitude-3 questions with Likert scale response format

- Activity assessment-2 questions with closed end -format

3. Questionnaire to assess prevalence of 8 common health problems related to body mass index

\section{Data collection}

Students were informed about the objective of the study and only willing students were included. Students were instructed to fill the questionnaire part of proforma. Height and weight were noted by trained volunteers. BMI was calculated and recorded in proforma of each student by volunteers.

\section{STATISTICALEVALUATION}

Descriptive statistics was done in Microsoft excel work sheet.

\section{RESULTS}

Total 153 students participated in survey

33 were boys and 120 girls

\section{KNOWLEDGE SURVEY}

All participants answered well to the open-ended knowledge question denoting they have very good idea on importance of healthy weight maintenance.

\section{ATTITUDE SURVEY}

Attitude questions probed 3 aspects. A persons likes vs health, taste vs health and how frequently he/she thinks about impact of his/ her activities on health.

\section{Graph 1: Likes vs health}

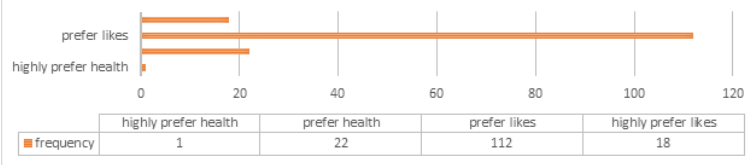

Most of the students answered that their likes are more important than health

Graph 2: taste vs health

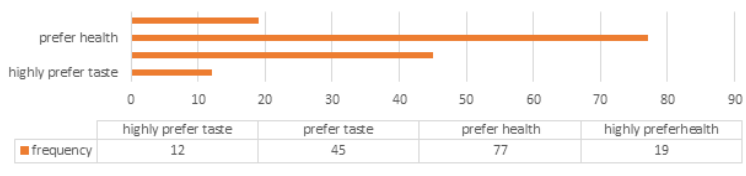

Most of the students want to prefer healthy food over tasty food.

Graph 3: Thoughts on health

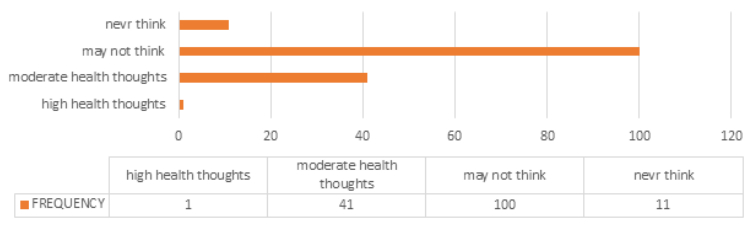

Most of the students responded that they seldom think about health when they take food or do activities.

\section{ACTIVITYASSESSMENT}

Graph 4:Total sleep hours

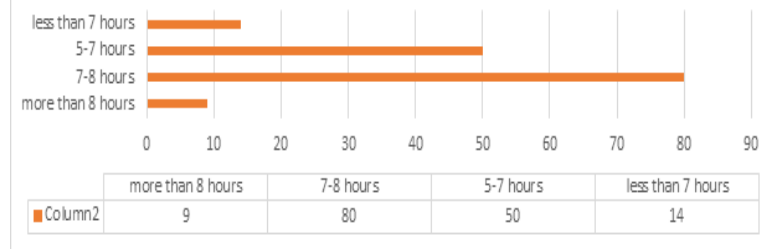




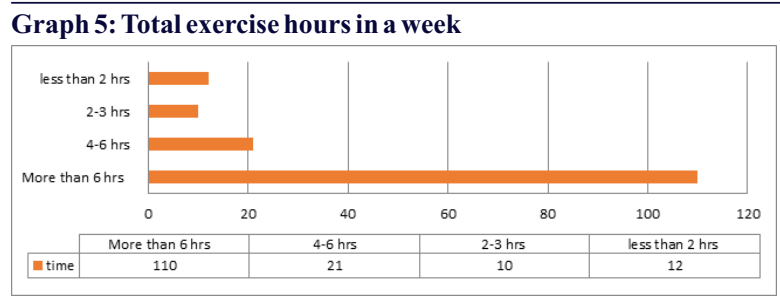

Most of students replied that they are doing adequate exercise, but there is a small population of students who is strikingly sedentary.

\section{Graph 6 : Distribution of health problems}

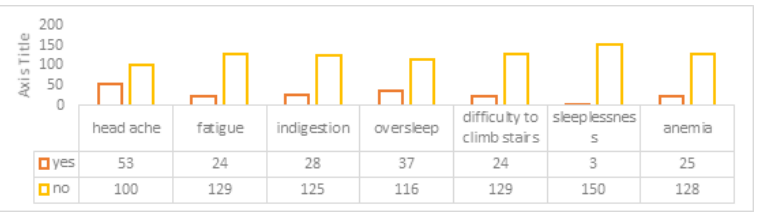

Headache was seen as the most troubling health problem since $35 \%$ of total students responded that they are having recurrent headaches.

\section{Graph 7: Distribution of BMI status}

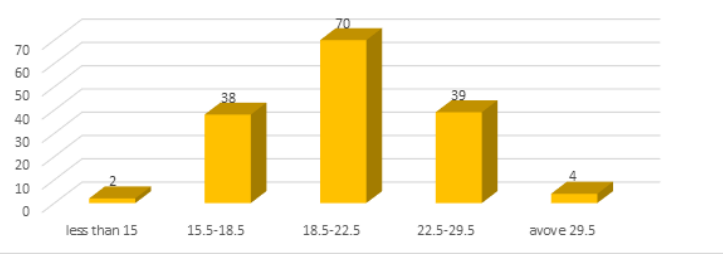

Peak in BMI curve is at the normal range with frequency of 70 students. But if sum of deviation from normalcy is taken, it comes to frequency of 83 students that require immediate attention. Very low $\mathrm{BMI}$ is reported which is untreated.

\section{DISCUSSION}

Being medical students' knowledge of health parameters was more but the attitude towards health was not satisfactory. Majority of the students have unhealthy BMI either over weight or underweight.

\section{RECOMMENDATIONS}

Self-care measures must be taught and encouraged among the students. Frequency of students having overweight and underweight need to be seriously attended and measures to maintain proper BMI should be enforced. Further study exploring the reasons for headache should be done, assessment of mental health parameters and menstrual health among girls may also be included.

\section{REFERENCES}

1. Park D E Preventive and social medicine:17. ed. Jabalpur:banarsidas bhanot;2002

Kothari, C.R, Gaurav garg. Research methodology methods and techniques. (3rd ed.). Mumbai: New age international (p) limited; 2014.

3. Krishna das, K.V. Textbook of medicine. (5th ed.). Newdelhi: Jaypee brothers medical publishers; 2008

4. Nicholas boon, A, Nicky colledge, R, Brian walker, R, John hunter, A.A. Davidson's principles and practice of medicine. (20th ed.). Philadelphia : Elsevier Publication; 2006 